\title{
OUTCOMES AFTER HYSTEROSCOPIC REPAIR OF SYMPTOMATIC ISTHMOCELE: A SINGLE CENTER EXPERIENCE IN UKRAINE
}

T.F. TATARCHUK

MD, professor, corresponding member of the NAMS of Ukraine, deputy director for research work, head of the Endocrine Gynecology Department, SI"O.M. Lukyanova Institute of Pediatrics, Obstetrics and Gynecology of the NAMS of Ukraine"; SRI "Center for Innovative Medical Technologies of the NAS of Ukraine", Kyiv ORCID: 0000-0002-5498-4143

N.V. KOSEI

$M D$, chief researcher at the Endocrine Gynecology Department, SI"O.M. Lukyanova IPOG of the NAMS of Ukraine", leading researcher at the SRI "CIMT of the NAS of Ukraine", Kyiv ORCID: 0000-0003-3085-3285

B.V. KHABRAT

$\mathrm{PhD}$, leading researcher at the Research Department of Minimally Invasive Surgery of the SRI"Scientific and Practical Center of Preventive and Clinical Medicine", The State Management of Affairs, Kyiv ORCID: 0000-0001-5224-9201

\section{T.M. TUTCHENKO}

$\mathrm{PhD}$, researcher of the Endocrine Gynecology Department, SI "O.M. Lukyanova IPOG of the NAMS of Ukraine"; SRI "CIMT of the NAS of Ukraine", Kyiv

ORCID: 0000-0002-3003-3650

\section{L.M. ZENKINA}

head of anesthesiology department, SRI "CIMT of the NAS of Ukraine", Kyiv ORCID: 0000-0001-8321-0481

M.I. HLAMAZDA

$\mathrm{PhD}$, postgraduate student,

SI"O.M. Lukyanova IPOG

of the NAMS of Ukraine", Kyiv

ORCID: 0000-0002-3653-4659

N.M. YEVTUSHENKO

highest category obstetrician-

gynecologist, head of treatment and surgical department of the Medical

centre "Verum", Kyiv

ORCID: 0000-0003-3993-5738

\section{Contacts:}

Nataliia V. Kosei

Center for Innovative Medical

Technologies of the NAS of Ukraine

22 Voznesenskiy Uzviz

04053, Kyiv, Ukraine

Tel.: +38 (044) 2721072

email: nataly.kosey@gmail.com

\section{INTRODUCTION}

Isthmocele (IC) (scar niche after Cesarean section (CS)) is a pocket-like defect of the uterine wall after CS, the result of incomplete healing of the myometrium of the isthmic part after the transverse incision in the lower segment during CS [1].

IC was first described by Poidevin using hysterosalpingography in 1961. In 1995 Morris H. discovered association of symptoms (abnormal uterine bleeding, pain) with this condition and introduced the term "Cesarean scar syndrome" [2].

The frequency of operative delivery continues to grow, reaching $30 \%$ in some countries, which makes the diagnosis and treatment of IC as a cause of abnormal uterine bleeding, pain, infertility, placenta accreta spectrum disorders and related complications more and more relevant $[3,4]$. There is currently no consensus definition/ description criteria for IC [1].

According to various sources the frequency of IC in women with symptoms ranges from 19\% to $84 \%$ [5]. In a random population of women after CS the use of transvaginal ultrasound and sonohysterography showed the frequency of IC of $56 \%$ and $84 \%$, respectively [6]. According to O. Vikhareva Osser et al., the probability of IC after one delivery by Caesarean section reaches $60 \%$, while after 3 Cesarian diliveries it reaches 100\% [7].

Abnormal uterine bleeding, pelvic pain, dysmenorrhea are the most typical symptoms of IC. The influence on fertility is very probable.

Transvaginal ultrasound and sonohysterography are the most appropriate and common methods used to visualize niches $[8,9]$. Recently guideline for detailed uterine niche evaluation by ultrasonography in the non-pregnant woman was issued by a group of European experts [10].

The following methods of IC treatment are used: hysteroscopic excision, laparoscopic excision, combined laparoscopic vaginal approach, vaginal operations, conservative management (combined contraceptive pills) [11, 12]. Currently method choice is based on residual myometrium thickness (RMT) and patient's reproductive plans. Data on each method effectiveness in different populations are still limited.

The aim of this study was to evaluate the influence of IC hysteroscopic repair on symptoms (abnormal uterine bleeding (AUB), dysmenorrhea) in premenopausal patients with RMT more than $2.4 \mathrm{~mm}$ and to assess myometrial thickness 3; 6 and 12 month post surgery.

\section{MATERIALS AND METHODS}

It was a prospective case series of symptoms evaluation following hysteroscopic IC repair in premenopausal women not willing to conceive. Diagnosis of IC was based on 2D transvaginal ultrasound (TVUS) and symptom evaluation. We used Delphi ultrasonographic niche measurement principles in ultrasonographic niche evaluation [10]. TVUS was performed in early proliferative phase. RMT above the vertex of the IC was measured in all patients. Patients with RMT $<2.4$ $\mathrm{mm}$, willing to conceive were recommended laparoscopic surgery according to existing approach and were not included in this study. Patients with coexisting uterine pathologies (myoma, adenomyosis, and endometrial polyps) were also not included in the surgery efficacy evaluation.

For hysteroscopy all patients were hospitalized, their somatic status was thoroughly examined. All patients eligible for hysteroscopic IC repair were performed sexually transmitted diseases and vaginal culture evaluation and treatment in case of positive result. Hysteroscopy was performed under general anesthesia by two experienced gynecological surgeons using the same equipment and technique. Initially, a diagnostic hysteroscopy using 5-mm, 30o angle lens, rigid hysteroscope (Karl Storz GmbH and Co, Germany), without cervical dilatation, was done in order to achieve direct view of the scar defect and to exclude other intrauterine anomalies. Afterwards, hysteroscopic niche resection was performed using a 9-mm (26 Fr) bipolar loop resectoscope (Karl Storz GmbH and $\mathrm{Co}, \mathrm{Germany})$. Anterior and posterior fibrotic arch of the IC were identified and resected until the bottom reached the level of the cervical canal. The bottom of the niche was coagulated.

Symptom frequency and residual myometrium thickness by ultrasound were evaluated before hysteroscopic repair and after 3, 6 and 12 months after it in patients with IC as single possible cause of symptoms.

\section{STUDY RESULTS}

In the period from January 2017 to January 2018 there were 32 cases of symptomatic IC with residual myometrium thickness of more than 2.4 $\mathrm{mm}$ in premenopausal women. $8(25 \%)$ of them 
had coexisting uterine pathology that could cause AUB and pain - 5 patients had adenomyosis, 2 - endometrial polyp, 1 - uterine myoma class 3 coexisting with endometrial polyp As shown in table 1 dismenorrhea, intermenstrual bleeding and AUB were the most frequent symptoms of IC in our study. Thus 24 cases were included in hysteroscopic repair efficacy analysis. All 24 patients underwent: hysteroscopy, resection of the edges of the niche, removal of fibrous tissue, coagulation of the bottom of the niche and polypectomy if necessary.

Table 1. Clinical characteristics of patients with IC eligible for hysteroscopic repair

\begin{tabular}{|c|c|c|}
\hline & Characteristics & Number (\%) \\
\hline \multirow{2}{*}{ Number of CS } & 2and more & $7(29.2)$ \\
\hline & 1 & $17(70.8)$ \\
\hline \multirow{3}{*}{ Symptoms } & AUB & $8(33.3)$ \\
\hline & Intermenstrual bleeding/spotting & $18(75)$ \\
\hline & Chronic pelvic pain & $6(25)$ \\
\hline & Dysmenorrhea & $22(91.7)$ \\
\hline & Dyspareunia & $9(37.5)$ \\
\hline & Infertility & $6(25)$ \\
\hline
\end{tabular}

Seven (29.2\%) patients had a history of more than one CS. The time period from the moment of symptoms initiation to the diagnosis of IC was from 3 months to 5 years. The thickness of the residual endometrium was from 2.6 to $6.9 \mathrm{~mm}$ (mean value $3.6 \pm 0.9$ ). Variants of shape and localization of niches are presented in Fig. 1.
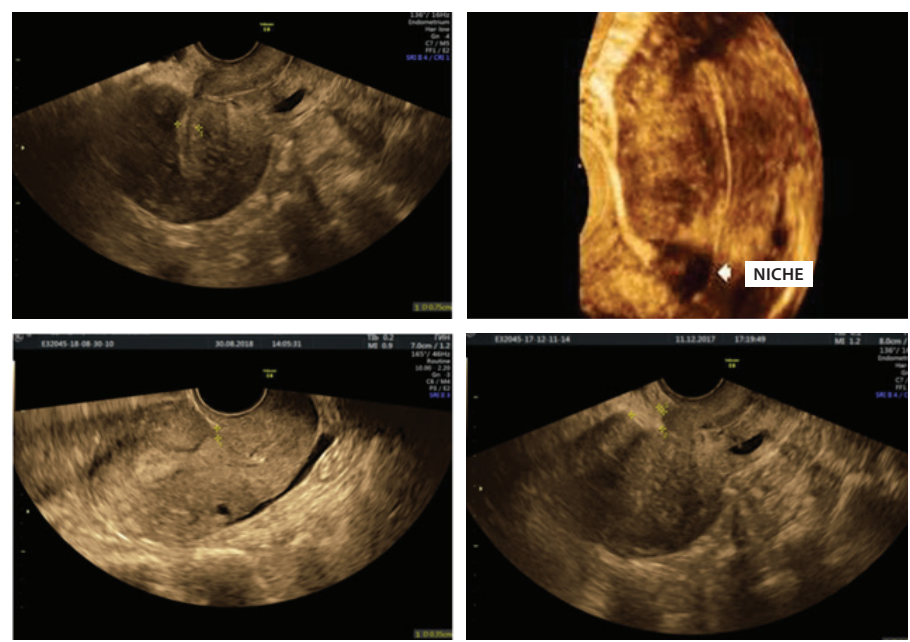

Figure 1. Variants of shape and localization of IC

All 24 patients underwent: hysteroscopy, resection of the edges of the niche, removal of fibrous tissue, coagulation of the bottom of the niche and polypectomy if necessary.
Prophylactic antibiotics and nonsteroidal anti-inflammatory drugs were used in all cases. All patients were discharged on the day of the surgery. No complications or adverse effects were reported after hysteroscopic IC repair. The minimum follow-up period after surgical treatment was 12 months. For all operated patients, barrier contraception was recommended for 3-6 months, followed by determination of further contraception choice on the planned visit.

Three months after surgery, most patients reported a complete relief of symptoms: AUB reduced from 33.3\% (8 patients) to $4.2 \%$ (1 patient); intermenstrual bleeding form $75 \%$ (18 patients) to $12.5 \%$ (3 patients); dysmenorrhea - from $91.7 \%$ ( 22 patients) to $29.2 \%$ (7 patients). This effect was even more prominent after 6 and 12 months (table2).

Average values of ultrasonographic assessment of the thickness of the myometrium in the area of the resected niche 3, 6 and 12 months after surgery are presented in Table 2 .

Figure 2 shows sonograms of a patient with IC and 2 scars after CS before and after hysteroscopic treatment.
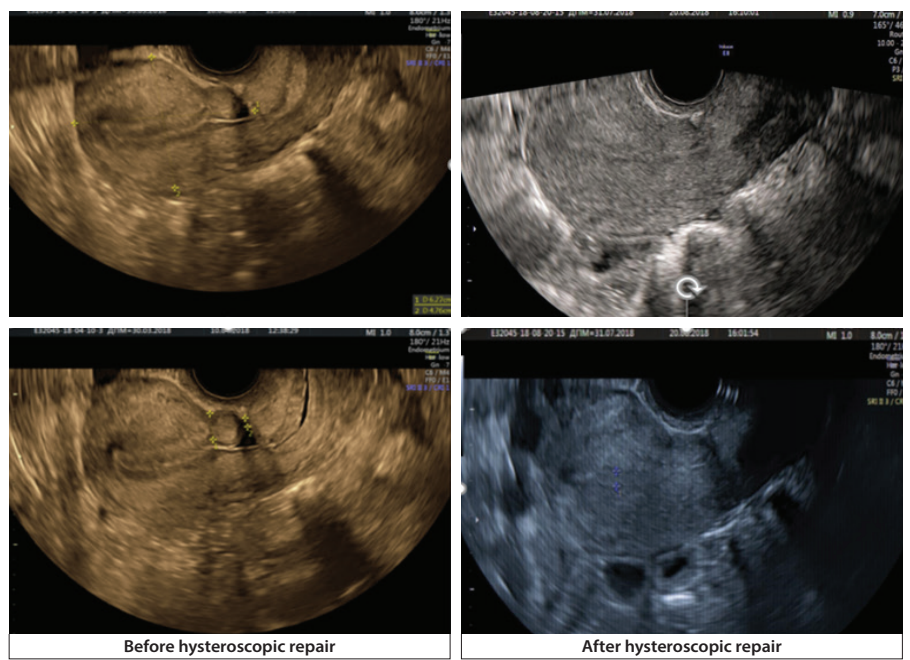

Figure 2. Sonograms of a patient with IC and 2 scars after CS before and after hysteroscopic treatment

\section{DISCUSSION}

Clinical consequences of IC have been underestimated for a long time. Today, the association of IC with AUB, dysmenorrhea, pain, dyspareunia, and obstetric complications is clearly proved $[9,13]$. The degree of influence of IC on fertility is not exactly known. In the meta-analysis of Gurol-Urganci et al. (2013) including 85 728 women with a history of CS a $10 \%$ reduction of the of subsequent pregnancy chances was reported (relative risk $0.91,95 \%$ confidence interval $0.87-0.95)$ [14].

Table 2. Average values of RMT (mm) and symptom frequency (\%) before hysteroscopic IC repair and 3; 6 and 12 months post surgery

\begin{tabular}{|c|c|c|c|c|}
\hline Parameters & $\begin{array}{c}\text { Before } \\
\text { hysteroscopic repair }\end{array}$ & $\begin{array}{c}3 \text { month after } \\
\text { hysteroscopic repair }\end{array}$ & $\begin{array}{c}12 \text { month after } \\
\text { hysteroscopic repair }\end{array}$ & \begin{tabular}{c} 
hysteroscopic repair \\
\hline RMT (mm)
\end{tabular} \\
\hline AUB & $3.6 \pm 0.9$ & $4.9 \pm 1.2$ & $5.9 \pm 1.0$ & $6.2 \pm 1.1$ \\
\hline Intermenstrual bleeding/spotting & $8(33.3)$ & $1(4.2)$ & 0 & 0 \\
\hline Chronic pelvic pain & $18(75)$ & $3(12.5)$ & $1(4.2)$ & 0 \\
\hline Dysmenorhea & $6(25)$ & $2(8.3)$ & $1(4.2)$ & 0 \\
\hline Dyspareunia & $22(91.7)$ & $7(29.2)$ & $2(8.3)$ & $1(4.2)$ \\
\hline
\end{tabular}


Results of symptoms structure in our study coincide with the data of other authors: dysmenorrhea, intermenstrual bleeding, AUB (mainly postmenstrual bleeding) and pelvic pain were the most frequent symptoms in premenopausal women with IC. The term from the symptom initiation to the time of diagnosis and treatment was rather long in our study which tells about gynecologists' low awareness about IC. Also, we found that among 32 patients initially referred to our clinic and diagnosed with IC, 8 (25\%) had coexisting uterine pathology, that could contribute to symptoms: most frequent adenomyosis and endometrial polyps.

The cause of pain and AUB in case of IC is seen in the limited ability of the uterus to contract in the scar area, as well as to the presence of a pocket-like defect in the myometrium where menstrual blood and thick mucus are accumulated. Abnormal scar tissue vascularization, dilatation and fragility of capillaries, lymphocytic infiltration of the scar, peritoneal tissue and endometrium, as a manifestation of chronic endometritis are also considered by different authors $[15,16]$. The role of endometrial polyps and adenomyosis as well as other uterine and endometrial pathology in the development of IC, its symptoms severity effectiveness of its surgical treatment is not studied.

There are various approaches to surgical treatment of IC. According to 2013 systematic review both hysteroscopy and laparoscopy are effective for the elimination of AUB and pain associated with IC [17]. Still there is not enough data to evaluate the effect of these approaches on fertility. The choice of the treatment approach is largely determined by the patient's reproductive plans and is based on the fact that the hysteroscopic approach can effectively eliminate symptoms (AUB, pain), but does not allow to restore the thickness of the endometrium and thus does not prevent obstetric complications [19]. J. Donnez group demonstrated the possibility of complete myometrium restoration as a result of laparoscopic correction [20].

Thus, to date, the following approaches to surgical treatment of IC have been adopted:

s for women not planning pregnancy, when residual myometrium thickness is more than $3 \mathrm{~mm}$, hysteroscopy is considered most appropriate;
3 for women planning a pregnancy, especially if the thickness of the residual myometrium is less than $3 \mathrm{~mm}$, laparoscopic resection of the niche and restoration of the myometrium with a multi-row suture is the method of choice for today [1].

Efficacy of hysteroscopic repair on symptom resolution was shown in observational and case-series studies [18-23]. Systematic review of 2017 reported that hysteroscopic treatment seems to be a promising option in the management of post cesarean scar defects, but still further research is needed on the problem in question [24]. After this systematic review publication there was one controlled study comparing the hysteroscopic repair of symptomatic IC to the expectant management. Its results showed the complete resolution of symptoms in $87 \%$ of the treated patients, with a significant difference compared to untreated women [25]. Recent study of A. Carrillo de Albornoz similarly showed excellent results of hysteroscopic repair on IC symptoms in a selected group of women, when other possible causes of AUB and pain were excluded [26].

The results of our study showed technical feasibility and good efficacy of hysteroscopic repair both in terms of symptoms of IC and in myometrial thickness restoration in a selected group of women without coexisting uterine pathology similar to previously reported data. At the same time the finding of a rather significant number of coexisting uterine pathology especially adenomyosis warrants specific studies of this group of patients in order to determine the need of specific approaches to hysteroscopic technique and concomitant medical treatment.

12 months follow up is among the strong features of our study while the absence of objective evaluation of AUB and pain with validated scoring scales is its main limitation.

\section{CONCLUSION}

Hysteroscopic repair of IC is a technically feasible, safe and highly effective procedure for symptoms (AUB, pelvic pain, dysmenorrhea) in women with other uterine pathology excluded and not willing to conceive. Efficacy and specific features of technical performance and medical treatment in cases with coexisting adenomyosis and other uterine pathology are to be defined in future studies as such cases are frequent.

\section{REFERENCES/ЛITEPATУPA}

\section{Petrozza, J.C.}

"Defining a systematic approach to cesarean scar defects." Fertil Steril 111 (2019): 475. doi: 10.1016/j.fertnstert.2019.01.010

2. Morris, H.

"Surgical pathology of the lower uterine segment caesarean section scar: is the scar a source of clinical symptoms?"Int J Gynecol Pathol 14 (1995): 16-20. Available from: [http://www.ncbi.nlm.nih.gov/ pubmed/7883420], last accessed Apr 6, 2019.

3. Chestnut, D.H.

"Cesarean delivery on maternal request: implications for anesthesia providers." Int J Obstet Anesth 15 (2006): 269-72. doi: 10.1016/j.

ijoa.2006.06.009

4. Pacheco, L.A., Resta, L., Tinelli, A., et al.

"The Cesarean Scar Complications." In: Manag. Ther. Late Pregnancy Complicat. Springer International Publishing. Cham (2017): 317-37 doi: 10.1007/978-3-319-48732-8_19

van der Voet, L., de Vaate, A.B., Veersema, S., et al.

"Long-term complications of caesarean section. The niche in the scar: a prospective cohort study on niche prevalence and its relation to abnormal uterine bleeding." BJOG An Int J Obstet Gynaecol 121

(2014): 236-44. doi: 10.1111/1471-0528.12542

6. Tower, A.M., Frishman, G.N.

"Cesarean Scar Defects: An Underrecognized Cause of Abnormal Uterine Bleeding and Other Gynecologic Complications." J Minim Invasive Gynecol 20 (2013): 562-72. doi: 10.1016/j.jmig.2013.03.008 Vikhareva Osser, 0., Jokubkiene, L., Valentin, L.

"High prevalence of defects in Cesarean section scars at transvaginal

ultrasound examination." Ultrasound Obstet Gynecol 34 (2009): 90-7. doi: $10.1002 /$ uog.6395

8. Pyra, K., Rio Tinto, H., Woźniak, S., Polskie Towarzystwo Ultrasonograficzne.

Journal of ultrasonography (2018). Available from: [http://yadda. icm.edu.pl/yadda/element/bwmeta1.element.psid-46a2ca29-172346cd-aa43-e318eacbce2d], last accessed Apr 8, 2019.

9. Drouin, 0., Bergeron, T., Beaudry, A., et al.

"Ultrasonographic Evaluation of Uterine Scar Niche before and after Laparoscopic Surgical Repair: A Case Report."Am J Perinatol Reports 04 (2014): e65-e68. doi: 10.1055/s-0034-1376187

10. Jordans, I.P.M., de Leeuw, R.A., Stegwee, S.I., et al.

"Sonographic examination of uterine niche in non-pregnant women: a modified Delphi procedure." Ultrasound Obstet Gynecol 53 (2019):

107-15. doi: 10.1002/uog.19049

11. El-Toukhy, T.

"Treatment of post-caesarean niche: the accumulation of evidence."BJOG An Int J Obstet Gynaecol 125 (2018): 335. doi: 10.1111/1471-0528.14823

12. Setubal, A., Alves, J., Osório, F., et al.

"Treatment for Uterine IC, A Pouchlike Defect at the Site of a Cesarean Section Scar."J Minim Invasive Gynecol 25 (2018). doi: 10.1016/j. imig.2017.09.022

13. Keag, O.E., Norman, J.E., Stock, S.J.

"Long-term risks and benefits associated with cesarean delivery for mother, baby, and subsequent pregnancies: Systematic review and meta-analysis."PLOS Med 15 (2018): e1002494. doi: 10.1371/journal. pmed. 1002494

14. Gurol-Urganci, I., Bou-Antoun, S., Lim, C.P., et al. "Impact of Caesarean section on subsequent fertility: a systematic review and meta-analysis." Hum Reprod 28 (2013): 1943-52. doi: 10.1093/humrep/det130

15. Iannone, P., Nencini, G., Bonaccorsi, G., et al.

"IC: From Risk Factors to Management." RBGO Gynecol Obstet 41 (2019): 044-52. doi: 10.1055/s-0038-1676109 
16. Antila-Langsjo, R.M., Maenpaa, J.U., Huhtala, H.S., et al.

"Cesarean scar defect: a prospective study on risk factors." Am J Obstet Gynecol 219 (2018): 458.e1-458.e8. doi: 10.1016/j.ajog.2018.09.004

17. van der Voet, L., Vervoort, A., Veersema, S., et al.

"Minimally invasive therapy for gynaecological symptoms related to a niche in the caesarean scar: a systematic review." BJOG An Int J Obstet Gynaecol 121 (2014): 145-56. doi: 10.1111/1471-0528.12537

18. Morris, $\mathrm{H}$

"Surgical pathology of the lower uterine segment caesarean section scar: is the scar a source of clinical symptoms?" Int J Gynecol Pathol 14 (1995): 16-20. Available from: [http://www.ncbi.nlm.nih.gov/ pubmed/7883420], last accessed Apr 8, 2019.

19. Gubbini, G., Centini, G., Nascetti, D., et al.

"Surgical Hysteroscopic Treatment of Cesarean-Induced IC in Restoring Fertility: Prospective Study." J Minim Invasive Gynecol 18 (2011):

234-7. doi: 10.1016/J.JMIG.2010.10.011
20. Fabres, C. Arriagada, P., Fernandez, C., et al.

"Surgical treatment and follow-up of women with intermenstrual

bleeding due to cesarean section scar defect." J Minim Invasive

Gynecol 12 (2005): 25-8. doi: 10.1016/j.jmig.2004.12.023

21. Raimondo, G., Grifone, G., Raimondo, D., et al.

"Hysteroscopic treatment of symptomatic cesarean-induced IC: a prospective study." J Minim Invasive Gynecol 22 (2015): 297-301. doi: 10.1016/j.jmig.2014.09.011

22. Wang, C.-J., Huang, H.-J., Chao, A., et al.

"Challenges in the transvaginal management of abnormal

uterine bleeding secondary to cesarean section scar defect." Eur J

Obstet Gynecol Reprod Biol 154 (2011): 218-22. doi: 10.1016/j. ejogrb.2010.10.016

23. Chang, Y., Tsai, E.M., Long, C.Y., et al.

"Resectoscopic treatment combined with sonohysterographic

evaluation of women with postmenstrual bleeding as a result of previous cesarean delivery scar defects." Am J Obstet Gynecol 200

(2009): 370.e1-370.e4. doi: 10.1016/j.ajog.2008.11.038

24. Abacjew-Chmylko, A., Wydra, D.G., Olszewska, H.

"Hysteroscopy in the treatment of uterine cesarean section scar diverticulum: A systematic review."Adv Med Sci 62 (2017): 230-9.

doi: 10.1016/J.ADVMS.2017.01.004

25. Muzii, L., Domenici, L., Lecce, F., et al.

"Clinical outcomes after resectoscopic treatment of cesarean-induced IC: a prospective case-control study." Eur Rev Med Pharmacol Sci 21

(2017): 3341-6. Available from: [http://www.ncbi.nlm.nih.gov/ pubmed/28829510], last accessed Dec 13, 2019.

26. Vegas Carrillo de Albornoz, A., Lopez Carrasco, I.

Montero Pastor, N., et al.

"Outcomes after Hysteroscopic Treatment of Symptomatic ICS

in Patients with Abnormal Uterine Bleeding and Pelvic Pain: A

Prospective Case Series." Int J Fertil Steril 13 (2019): 108-12. doi:

10.22074 /ijfs.2019.5704

OUTCOMES AFTER HYSTEROSCOPIC REPAIR OF SYMPTOMATIC ISTHMOCELE: A SINGLE CENTER EXPERIENCE IN UKRAINE

T.F. Tatarchuk, MD, professor, corresponding member of the NAMS of Ukraine, deputy director for research work, head of the Endocrine Gynecology Department, SI "O.M. Lukyanova IPOG of the NAMS of Ukraine"; SRI "CIMT of the NAS of Ukraine",

Kyiv

N.V. Kosei, MD, chief researcher at the Endocrine Gynecology Department, SI "O.M. Lukyanova IPOG of the NAMS of Ukraine", leading researcher at the SRI "CIMT of the NAS of Ukraine", Kyiv

B.V. Khabrat, PhD, leading researcher at the Research Department of Minimally Invasive Surgery of the SRI "Scientific and Practical Center of Preventive and Clinical Medicine", The State Management of Affairs, Kyiv

T.M. Tutchenko, PhD, researcher of the Endocrine Gynecology Department, SI "O.M. Lukyanova IPOG of the NAMS of Ukraine"; SRI "CIMT of the NAS of Ukraine", Kyiv

L.M. Zenkina, head of anesthesiology department, SRI "CIMT of the NAS of Ukraine", Kyiv

M.I. Hlamazda, PhD, postgraduate student, SI "O.M. Lukyanova IPOG of the NAMS of Ukraine", Kyiv

N.M. Yevtushenko, highest category obstetrician-gynecologist, head of treatment and surgical department of the Medical centre "Verum", Kyiv

Purpose of the study was to evaluate the influence of Isthmocele (IC) hysteroscopic repair on symptoms (abnormal uterine bleeding, dysmenorrhea) in premenopausal patients with residual myometrium thickness more than 2.4 mm and to assess myometrial thickness 3,6 and 12 month post surgery.

Materials and methods. It was a prospective case series of symptoms evaluation and myometrium thickness following hysteroscopic IC repair in premenopausal women not willing to conceive. Diagnosis of IC was based on $2 \mathrm{D}$ transvaginal ultrasound and symptom evaluation. Symptom frequency and residual myometrium thickness by ultrasound were evaluated before hysteroscopic repair and after 3,6 and 12 months after it in patients with IC as single possible cause of symptoms. Results. In the period from January 2017 to January 2018 there were 32 cases of symptomatic IC in premenopausal women. 8 (25\%) of them had coexisting uterine pathology that could cause AUB, these women were not included in hysteroscopic treatment efficacy analysis. Thus 24 patients with residual myometrium thickness of more than $2.4 \mathrm{~mm}$ and not willing to conceive underwent hysteroscopic repaire of IC. Three months after surgery, most patients reported a complete relief of symptoms: abnormal uterine bleeding reduced from 33.3\% (8 patients) to 4.2\% (1 patient); intermenstrual bleeding form $75 \%$ (18 patients) to $12.5 \%$ ( 3 patients); dysmenorrhea - from $91.7 \%$ ( 22 patients) to 29.2 ( 7 patients). This effect was even more prominent after 6 and 12 months. Average residual myometrium thickness values changed in the following way: $3.6 \pm 0.9$ before surgery; $4.9 \pm 1.2 \mathrm{~mm}$ after $3 \mathrm{months} ; 5.9 \pm 1.0 \mathrm{~mm}$ after 6 month and $6.5 \pm 1.1 \mathrm{~mm}$ after 12 months. Conclusion. Hysteroscopic repair of IC is a technically feasible, safe and highly effective procedure for symptoms (abnormal uterine bleeding, pelvic pain, dysmenorrhea) in women with other uterine pathology excluded and not willing to conceive. Efficacy and specific features technical performance and medical treatment in cases with coexisting adenomyosis and other uterine pathology are to be defined in future studies as such cases are frequent.

Keywords: isthmocele, transvaginal ultrasound, adenomyosis, abnormal uterine bleeding, dysmenorrhea, hysteroscopy.

\section{ЕФЕКТИВНІСТЬ ГІСТЕРОСКОПІЧНОЇ КОРЕКЦІЇ СИМПТОМНОГО ІСТМОЦЕЛЕ: АНАЛІЗ ДОСВІДУ В КЛІНІЦІ В УКРАЇНІ}

Т.Ф. Татарчук, Д. мед. н., професор, член-кореспондент НАМН України, заступник директора з наукової роботи, завідувачка відділенням ендокринної гінекологї ДУ «ІПАГ ім. О.М. Лук'янової НАМН України»; ДНУ «ЦІМТ НАН України», м. Київ

Н.В. Косей, Д. мед. Н., головний науковий співробітник відділення ендокринної гінекології ДУ «ППАГ ім. О.М. Лук'янової НАМН України», провідний науковий співробітник ДНУ «ЦІМТ НАН України», м. Київ

Б.В. Хабрат, к. мед. н., провідний науковий співробітник наукового відділу малоінвазивної хірургї̈ ДНУ «Науково-практичний центр профілактичної та клінічної медицини» Державного управління справами, м. Київ

Т.М. Тутченко, к. мед. Н., науковий співробітник відділення ендокринної гінекології ДУ «ІПАГ ім. О.М. Лук'янової НАМН України»; ДНУ «ЦІМТ НАНУкраїни» м. Київ

Л.М. Зенькіна, завідувачка відділенням анестезіологї̈ ДНУ «ЦІМТ НАНУкраїни», м. Київ

М.І. Гламазда, К. меД. Н., аспірант очної форми навчання, ДУ «ППАГ ім. О.М. Лук'янової НАМнУкраїни», м. Київ

Н.М. Євтушенко, лікар акушер-гінеколог вищої категорії, завідувачка лікувально-хірургічним підрозділом МЦ «Верум», м. Київ

Метою дослідження стала оцінка впливу гістероскопічного відновлення істмоцеле (ІЦ) на симптоми (аномальні маткові кровотечі, дисменорея) у пацієнток репродуктивного віку з резидуальною товщиною міометрія понад 2,4 мм та оцінка товщини міометрія через 3, 6 та 12 місяців після операції.

Матеріали та методи. Це було проспективне дослідження серії випадків динаміки симптомів та товщини міометрія після гістероскопічної корекції ЦЦ ужінок репродуктивного віку, які не мали репродуктивних планів. Діагностика ІЦ базувалася на 2D-трансвагінальному УзД та оцінці симптомів до гістероскопічного відновлення і через 3, 6 та 12 місяців після нього у пацієнток із ІЦ як єдиною можливою причиною симптомів.

Результати. У період з січня 2017 року по січень 2018 року було зареєстровано 32 випадки симптоматичного ІЦу жінок репродуктивного віку. 8 (25\%) 3 них мали супутню патологію матки, яка могла викликати аномальні маткові кровотечі, ці жінки не були включені до аналізу ефективності гістероскопічного лікування. Таким чином, 24 пацієнткам без репродуктивних планів із резидуальною товщиною міометрія понад 2,4 мм було проведене гістероскопічне лікування ІЦ. Через три місяці після операції більшість пацієнток повідомили про повне полегшення симптомів: частота аномальних маткових кровотеч знизилася від 33,3\% (8 пацієнток) до 4,2\% (1 пацієнтка); міжменструальні кровотечі - від 75\% (18 паціенток) до 12,5\% (3 пацієнтки); дисменорея - від 91,7\% (22 пацієнтки) до 29,2\% (7 пацієнток). Цей ефект був ще помітнішим через 6 та 12 місяців. (ередні значення резидуальної товщини міометрія змінювались таким чином: $3,6 \pm 0,9$ мм перед операцією; $4,9 \pm 1,2$ мм через 3 місяці; $5,9 \pm 1,0$ мм через 6 місяців і6,5 $\pm 1,1$ мм через 12 місяців.

Висновок. Гістероскопічна корекція ІЦ є технічно здійсненною, безпечною та високоефективною процедурою щодо симптомів (аномальні маткові кровотечі, тазовий біль, дисменорея) за умови виключення інших причин та відсутності репродуктивних планів. Ефективність та специфічні технічні особливості операції та медикаментозного лікування у випадках із наявним аденоміозом та іншою патологією матки мають бути визначені у майбутніх дослідженнях, оскільки такі випадки є частими.

Ключові слова: істмоцеле, трансвагінальне УзД, аденоміоз, аномальні маткові кровотечі, дисменорея, гістероскопія.

\section{ЭФФЕКТИВНОСТЬ ГИСТЕРОСКОПИЧЕСКОЙ КОРРЕКЦИИ СИМПТОМАТИЧЕСКОГО ИСТМОЦЕЛЕ: АНАЛИЗ ОПЫТА В КЛИНИКЕ В УКРАИНЕ}

Т.Ф. Татарчук, Д. мед. н., профессор, член-корреспондент НАМН Украины, заместитель директора по научной работе, заведующая отделением эндокринной гинекологии ГУ «иПАГ им. Е.М. Лукьяновой НАМН Украины»; ГНУ «ЦИМТ НАНУкраины|», г. Киев

Н.В. Косей, Д. мед. Н., главный научный сотрудник отделения эндокринной гинекологии ГУ «ИПАГ им. Е.М. Лукьяновой НАМН Украины», ведущий научный сотрудник ГНУ «ЦИМТ НАН Украины», г. КиеВ

Б.В. Хабрат, К. мед. Н., Ведущий научный сотрудник научного отдела малоинвазивной хирургии ГНУ «Научно-практический центр профилактической и клинической медицины» Государственного управления делами, г. Киев

Т.Н. Тутченко, к. мед. Н., научный сотрудник отделения эндокринной гинекологии ГУ «ИПАГ им. Е.М. Лукьяновой НАМН Украины»; ГНУ «ЦИМТ НАН Украины», г. Киев

Л.Н. Зенькина, заведующая отделением анестезиологии ГНУ «ЦИМТ НАНУкраины», г. Киев

М.И. Гламазда, К. мед. Н., аспирант очной формы обучения, ГУ «ИПАГ им. Е.М. Лукьяновой НАМН Украины», г. Киев

Н.Н. Евтушенко, врач акушер-гинеколог высшей категории, заведующая лечебно-хирургическим подразделением МЦ «Верум», г. Киев

Целью исследования стала оценка влияния гистероскопического восстановления истмоцеле (ИЦ) на симптомы (аномальные маточные кровотечения, дисменорея) у пациенток репродуктивного возраста с резидуальной толщиной миометрия более 2,4 мм и оценка толщины миометрия через 3, 6 и 12 месяцев после операции.

Материалы и методы. Это было проспективное исследование серии случаев динамики симптомов и толщины миометрия после гистероскопической коррекции ИЦ у женщин репродуктивного возраста, не имевших репродуктивных планов. Диагностика ИЦ базировалась на 2D-трансвагинальном УЗИ и оценке симптомов до гистероскопического восстановления и через 3,6 и 12 месяцев после него у пациенток с ИЦ как единственно возможной причиной симптомов.

Результаты. В период с января 2017 по январь 2018 было зарегистрировано 32 случая симптоматического ИЦ у женщин репродуктивного возраста. 8 (25\%) из них имели сопутствующую патологию матки, которая могла вызвать аномальные маточные кровотечения, эти женщины не были включены в анализ эффективности гистероскопического лечения. Таким образом, 24 пациенткам без репродуктивных планов с резидуальной толщиной миометрия более 2,4 мм было проведено гистероскопическое лечение ИЦ. Через три месяца после операции большинство пациенток сообщили о полном облегчении симптомов: частота аномальных маточных кровотечений снизилась с 33,3\% (8 пациенток) до 4,2\% (1 пациентка), межменструальные кровотечения - с 75\% (18 пациенток) до 12,5\% (3 пациентки), дисменорея - с91,7\% (22 пациентки) до 29,2\% (7 пациенток). Этот эффект был еще более заметен через би 12 месяцев. Средние значения резидуальной толщины миометрия изменялись следующим образом: 3,6 0 0,9 мм перед операцией; 4,9 $\pm 1,2$ мм через 3 месяца; 5,9 $\pm 1,0$ мм через 6 месяцев и 6,5 $\pm 1,1$ мм через 12 месяцев. Вывод. Гистероскопическая коррекция ИЦ является технически осуществимой, безопасной и высокоэффективной процедурой в отношении симптомов (аномальные маточные кровотечения, тазовая боль, дисменорея) при условии исключения других причин и отсутствия репродуктивных планов. Эффективность и специфические технические особенности операции и медикаментозного лечения в случаях с имеющимся аденомиозом и другой патологией матки должны быть определены в будущих исследованиях, поскольку такие случаи являются частыми. 